Cruise and Cruise Ports: Structures and Strategies

Special Issue of 'Research in Transportation Business \& Management'

Volume Editors: Athanasios Pallis, Jean-Paul Rodrigue, Theo Notteboom

\title{
Power in the context of cruise destination stakeholders' interrelationships
}

\author{
Wendy R London \\ wendy.london@griffithuni.edu.au
}

Griffith Institute for Tourism - GIFT

Griffith University, Nathan Campus, Brisbane QLD 4111 Australia

Gui Lohmann

g.lohmann@griffith.edu.au

Griffith Institute for Tourism (GIFT) \& Urban Research Program (URP)

Griffith University, Nathan Campus, Brisbane QLD 4111 Australia

\begin{abstract}
The growth of cruise tourism worldwide presents cruise destinations with many challenges, including the need for substantial investment in cruise infrastructure. This paper reviews the role and manifestations of power among a wide range of cruise destination stakeholders and the cruise lines with respect to the commercial and political negotiations that arise in relation to this investment. The framework for this review considers (a) type of port (e.g. home/turnaround port or port-of-call); (b) the stakeholders who have an interest in cruise destinations or are impacted by the activities related to them; (c) the cruise destination's stage of development (i.e. proposed, mature or declining); (d) port characteristics and (e) a determination of whether it is the cruise line or the cruise destination who initiates the proposal for cruise infrastructure development. This review makes evident that power is a complex factor, which can be exercised or received, by any of the stakeholders and that power is influenced by a variety of factors and interests.
\end{abstract}

\section{Keywords}

Cruise destinations; cruise tourism; power; stakeholders 


\section{Introduction}

Cruise tourism continues to grow worldwide, not only in the number of passengers, but also in the number of cruise ships deployed, the size of ships being constructed and the number of new destinations being introduced. For example, the number of passengers grew from 3.7 million in 1990 (Cruise Market Watch 2014) to 21.4 million in 2013 (Florida-Caribbean Cruise Association (F-CCA) 2013). In the past decade alone, there has been a 77 per cent increase in the demand for cruising from 12 million passengers to 21.3 million (Cruise Line International Association (CLIA) 2014). Translated into economic terms, this growth represents a US\$117 billion contribution to the global economy and 890,000 full-time jobs (CLIA 2014). In order to support this growing demand, the North American fleet alone will grow by 26 new ships through 2016 (F-CCA2013). This growth presents cruise destinations wishing to attract cruise ships with several challenges as well as risks, especially given the large investments required for infrastructure development for both new and mature destinations. Thus, the stakes are high, with destinations seeking to take more of the cruise tourism pie and cruise lines seeking more destinations to refresh their itineraries. There are other benefits as well. For example, the decision to invest in cruise-related structures such as cruise terminals can foster the development or re-development of brownfield sites and promote urban redevelopment. In a similar vein, incorporating cruise terminals into multi-purpose waterfront developments can be a desirable addition for investors and developers who seek to diversify their investment in and usage of those facilities. Commercial ports can benefit from the introduction of cruise shipping as an added revenue stream, although the investment in cruise infrastructure can be costly and the presence of cruise ships may result in the displacement or loss of commercial shipping traffic. Local communities may view cruise tourism as economically beneficial and treat the presence of cruise ships with a fair degree of pride, despite the negative effects, which can occur (e.g. air and water pollution, crowd congestion etc.).

However, in many destinations, the development of cruise tourism does not always follow a clear path. Often, this can be attributed to a lack of coordination on the government or policy level (London 2010) whilst in others; it can be attributed to a lack of collaboration or understanding at 
the community level. In both cases, weaknesses in cruise tourism planning can be attributed to a wide variety of reasons ranging from the excitement generated by a single ship calling into a port which had never received cruise ships to one or more stakeholders exercising their asymmetric power to achieve their unilateral objectives such as securing a casino licence (Skene 2014). While a substantial amount of literature about stakeholder relationships can be found in the general tourism literature (see e.g. Jamal \& Getz 1995; Sautter \& Leisen 1999), little can be found relating to cruise tourism generally (see e.g. Lester \& Weeden 2004; Stewart \& Draper 2006) and even less about proposals for cruise infrastructure development (see e.g. Johnson \& Lyons 2011) and cruise destination stakeholders' relationships with the cruise lines. More specifically, little is known about how cruise destination stakeholders assert power in anticipation of and in response to the cruise lines' power, how those stakeholders interact within the destination and how the assertion of that power impacts those stakeholders in the context of attracting and accommodating cruise ships. Instead, existing literature focuses on the cruise lines' corporate power such as their oligopolistic power (Wie 2005), the mobility of their assets (i.e. their ships) (Chin 2008) and the deterritorialized regulatory environment in which they operate (Wood 2004).

This paper partially addresses these shortcomings by providing a theoretical contribution in respect of how power operates between cruise destination stakeholders and the cruise lines and amongst those destination stakeholders. In particular, this paper seeks to analyse who exercises power, identifying the factors which may affect the stakeholders' perception and exercise of power and which events trigger the use of power. Accordingly, we suggest a framework which incorporates many of the factors, which appear to be relevant to a determination of how power is exercised and received by stakeholders who have an interest in cruise infrastructure development. The motivation for creating such a framework can be found in the reported cases presented in this paper. Each of these cases represents a different balance of the factors found in our suggested framework, thereby leading to different reasons for the development of cruise infrastructure and ultimately, a different result. Thus, the purpose of this paper is to outline some of the increasingly significant issues facing cruise destinations with respect to proposals or plans for cruise infrastructure development, and through the application of our framework, to begin to 
develop an understanding of those issues with a particular focus on how the exercise and receipt of power impacts the manifestation and balance of those factors.

\section{Power in the context of cruise destinations}

\section{Theories of power}

The literature on power is broad and complex. Foucault adopts a decidedly social approach, based on an assumption that power is shared and inherently "present in all relations" (Wearing \& McDonald 2002, p 196). In contrast, Lukes' (1974) exposition of power reveals three fundamentally different views, i.e. one-, two- and three-dimensional power, each with its own proponents and each turning on a range of factors which includes (a) the behavior of the dominant and submissive actors; (b) the existence (or not) of decision-making capability; (c) the presence (or not) of observable conflict; and (d) the quality or nature of the interests or preferences involved. According to Lukes (1974), one-dimensional power (the pluralist view) is present when one actor, Actor A, has actual power over Actor B and can force B to do something that B would otherwise not do.

Perhaps even more relevant is Lukes' concept of two-dimensional power in which he characterises decisions as "a choice among alternative modes of action” (1974, p 39). It is in fact choice, and more specifically the choices that both the cruise lines and the destination stakeholders make with respect to cruise destinations, which form the basis of this paper. For example, cruise lines can choose whether to consider, visit, avoid, abandon, re-visit or substitute a port while cruise destinations can choose whether or not to accommodate cruise ships. In the case of the cruise lines and the choice of ports, this choice can be manifested in several ways. For example, an otherwise desirable or popular port may be dropped because of an increase in fuel prices or a requirement that lighter fuel, which is more costly, be used making it more expensive for ships to reach that port. Well-publicised examples include Antarctica and Svalbard (Eijgelaar, Thaper \& Peeters 2010). Other ports may be avoided or cancelled for one or more scheduled port calls because of poor weather (particularly during the start or end of a cruise season); security threats (e.g. Egypt and Israel); mechanical difficulties affecting the ship (e.g. a broken engine propeller or stabiliser); widespread illness aboard the ship, resulting in delays and cancelled ports as the ship is thoroughly cleaned; or an inability to refuel or re-provision as 
originally planned. Other ports may be abandoned and then re-visited. Examples include Alaska when a US\$46 per passenger tax was imposed (Mak 2008), resulting in a significant reduction of cruise traffic as the cruise lines sought less burdensome markets. Once the tax was reduced (Bohrer 2010), the State experienced an increase in cruise traffic. Conversely, a cruise line may consider a port (e.g. Gisborne, New Zealand) by making one or two preliminary port calls, and then adding that port on a more regular basis (Gisborneherald.co.nz 2013). Lukes (1974) also argues that the two-dimensional view of power introduces the question of control. Control is a core element of the market position of dominant firms, the position deemed to be occupied by the cruise lines and other stakeholders described in this paper (e.g. developers and governments). Lukes' (1974) premise that actual power is required can therefore be distinguished from Foucault's social approach.

In the context of cruise destinations, it seems appropriate to frame this research within the parameters of organisations and agencies that are the repositories of power (Clegg 1989). Specifically, this research focuses on the interrelationships of several pertinent cruise destinations stakeholders with respect to the control, trust, commercial relationships, transactions, ownership and management of physical assets as exercised by those organisations and agencies.

\section{Tourism-specific theories of power}

As the focus of this research is on cruise destinations, it is appropriate to consider tourismspecific theories of power. Tourism-specific theories can be found in the literature although they are usually cast in terms of tourism consumption and the operation of tourism within the greater political, cultural and social context (Coles \& Church 2007). Some of these theories include a Foucauldian view of destinations, hosts and agencies (Cheong \& Miller 2000); a participatory development approach involving community-based tourism (Wearing \& McDonald 2002); a demonstration of the link between power, tourism and the environment; a feminist approach; and the role of power in the context of sexuality and tourism (Coles \& Church 2007). In other words, most of the literature to date dealing with the power and tourism nexus appears to mention power as it applies to the empowerment of destinations and actors rather than to the power or control exerted by stakeholders who have an interest in the tourism industry. It is only 
relatively recently that a view of economic power in tourism has begun to evolve (Clancy 2008; Tejada, Santos \& Guzmán 2011). The emergence of this literature is significant because it provides a basis for analysing how oligopolistic enterprises and destination stakeholders exercise power as part of their commercial negotiations. More significantly, it provides a means for testing whether the success (or failure) of these negotiations is likely to be determinative of the cruise lines' choice of ports and whether there is any difference in situations where the cruise line approaches the cruise destination or vice-versa.

\section{The power of cruise lines, shore-side enterprises and the community}

Within the context of cruise destinations, the ultimate focus of relevant theories of power is economic power. This power may manifest on several levels including the economic power which cruise lines assert in their relationships with the ports and the economic power which cruise destinations assert with respect to constructing cruise facilities and attracting cruise ships.

A fundamental manifestation of cruise line power is evident in how cruise lines choose the ports they visit. Klein argues that cruise lines “play ports off one another” (2005, p. 266), implying that the cruise lines wield their power to secure the best possible commercial gain or more specifically, the best possible use of or access to a destination's cruise terminal. Klein's (2005) comments raise important questions because ultimately, the discussion about choice of destinations is a financial one based on whether cruise lines make or lose money for their shareholders. In the quest to maximise shareholder return, cruise lines constantly seek to create new products including, for example, promoting the ship as a destination in itself to maximise onboard spending (Gui \& Russo 2011). However, interesting destinations remain one of the most important draw cards to attract passengers, thereby rendering the success or failure of a destination's engagement with the cruise lines determinative of whether the cruise lines visit or continue to visit that destination.

Power is also harboured by cruise destination stakeholders. A critical factor in the success or failure of a cruise destination is how government at all levels, the business sector and the community respond to and engage with the more encompassing oligopolistic power asserted not only by the cruise lines but also by other enterprises such as non-local developers and investors 
which may also harbour potentially asymmetric power. A cruise destination's power may be manifested in the form of the destination offering a cruise line a management or ownership role in the destination's cruise terminal (Gui \& Russo 2011) or through financial or other incentives for cruise lines to call into its port (Ryan 2012). Power can also operate in relation to other groups of stakeholders including developers, real estate investors or even government authorities who are developing, building or expanding cruise terminals - e.g. the Gold Coast (Australia) (Associated Australian Press 2014); Singapore (Singapore Tourism Board 2009); and Dubai (Cornwell 2013). Community groups can also exercise power in relation to the construction of cruise terminals and the presence of cruise ships - e.g. the Gold Coast (Australia) (Dredge 2010); Venice (Reuters 2013); and Charleston, South Carolina (Severson 2013).

\section{Power and risk}

Although this paper explores the power relationships among cruise destination stakeholders, risk is intrinsically associated with power and also needs to be addressed. Risk can attach to and arise from the relationships as well as the commercial agreements between parties to those agreements. Significantly, it should be noted that risk is no longer considered to be a matter of mere loss but instead involves choice (Roehl \& Fesenmaier 1992), a view which is entirely consistent with and supports the discussion presented in this paper, i.e. choices related to the development and use of cruise facilities within cruise destinations. For example, a cruise destination which decides to build a terminal risks the possibility that no ships will turn up, a choice exercised by the cruise lines. If the cruise terminal is part of a larger commercial port operation, the port can choose to displace commercial shipping with cruise shipping.

In cases where a cruise line vertically integrates its supply chain (including contracting with global ground-handling organisations) (Di Vaio \& Romana Medda 2010), there is a significant risk that revenues realised in respect of that destination will flow offshore rather than to local businesses which can provide the same services (Gui \& Russo 2011). Another aspect of the risk which must be borne by cruise destinations is that there may be a lack of communication concerning a change in the size of ships which the cruise lines plan to deploy over the mediumand long-term future. Most notably, some recently constructed terminals are now obsolete or soon will be, in large part because of the rapid increase in the number of mega-ships (i.e. ships of 
more than 100,000 gross registered tonnes). These large ships cannot be accommodated at terminals or piers designed for smaller ships nor can they sail under bridges which are too low (e.g. Brisbane River Bridge, the Sydney Harbor Bridge and the bridge over Busan, Korea’s harbor), thereby preventing them from reaching terminals which are beyond those bridges.

There also many risks associated with the cruise destination itself including realisation of the fact that cruise tourism is generally seasonal (Charlier \& McCalla 2006). For example, construction of a cruise terminal may not make economic sense unless the terminal is designed as a multi-use facility which can be used throughout the year (McCarthy \& Romein 2012). In other cases, the introduction of cruise tourism can change the character of the cruise destination. For example, the arrival of cruise ships in Key West, Florida has resulted in crowd congestion, an increase in fast food restaurants and souvenir shops and a reduction in the number of hotels (now converted to apartments because the 'new' visitors, i.e. cruise passengers, return to their cabins after their day on-shore) (Hritz \& Cecil 2008). Another example of the risk of alienating or marginalising the local community can be found in Darwin, Australia. Local protest groups felt that they were not consulted in the design and building of the new waterfront and cruise terminal facilities, maintaining that the government was more concerned with enhancing the city's tourism profile and acceding to investors and developers from outside the Territory rather than benefiting locals (Schmalleger \& Carson 2010).

\section{Proposed framework}

Our proposed framework for investigating the role and manifestations of power in the context of cruise infrastructure development incorporates five elements which are presented in the coming subsections. These elements were identified as particularly relevant in a thorough analysis of the cruise tourism literature and can be summarised in Table 1:

Table 1: Proposed framework

\begin{tabular}{|l|l|}
\hline Element & \multicolumn{1}{|c|}{ Description } \\
\hline Type of port & $\begin{array}{l}\text { A determination of whether the cruise destination hosts a turnaround (home) } \\
\text { port, a port-of-call or a hybrid port (where the port is both a turnaround port and }\end{array}$ \\
\hline
\end{tabular}




\begin{tabular}{|c|c|}
\hline & a port-of-call). \\
\hline Stakeholders & $\begin{array}{l}\text { Individuals and institutions who either have a vested interest in cruise } \\
\text { infrastructure development or are impacted by it. }\end{array}$ \\
\hline $\begin{array}{l}\text { Stage of } \\
\text { development }\end{array}$ & A cruise destination's stage of development. \\
\hline $\begin{array}{l}\text { Port } \\
\text { characteristics }\end{array}$ & $\begin{array}{l}\text { Characteristics relating to the operational focus of the port (commercial or } \\
\text { cruise), the port's ownership, financing governance and management. }\end{array}$ \\
\hline $\begin{array}{l}\text { Origin of } \\
\text { proposal }\end{array}$ & $\begin{array}{l}\text { The origin of the proposal for cruise infrastructure is viewed as the event, which } \\
\text { triggers the use of power, evoking responses that differ as to whether the initiator } \\
\text { is the cruise line or the cruise destination. }\end{array}$ \\
\hline
\end{tabular}

Each of these elements is discussed below.

\section{Type of port}

Marti (1990) identifies three different types of cruise ports, i.e. (a) home (or turnaround) ports;

(b) ports of call; and (c) hybrid ports. Each type embraces different characteristics and level of required investment (Table 2).

Table 2: Cruise port types

\begin{tabular}{|l|l|l|l|}
\hline $\begin{array}{l}\text { Type of } \\
\text { port }\end{array}$ & Description & Investment & Examples \\
\hline Home & $\begin{array}{l}\text { Passengers } \\
\text { embark or } \\
\text { disembark at }\end{array}$ & $\begin{array}{l}\text { Require substantial investment in } \\
\text { services and facilities such as: baggage } \\
\text { handling services; full immigration and } \\
\text { the beginning } \\
\text { or end of their } \\
\text { cruise, }\end{array}$ & $\begin{array}{l}\text { Miamiroms services; additional } \\
\text { environmental and ship servicing } \\
\text { facilities; access to long distance }\end{array}$ \\
\end{tabular}




\begin{tabular}{|l|l|l|l|}
\hline respectively. & $\begin{array}{l}\text { transport networks and long-term parking } \\
\text { facilities; sufficient accommodation for } \\
\text { passengers and crew pre- and post-cruise. }\end{array}$ & $\begin{array}{l}\text { Sydney (Australia); } \\
\text { Vancouver (Canada) }\end{array}$ \\
\hline $\begin{array}{l}\text { Port of } \\
\text { call }\end{array}$ & $\begin{array}{l}\text { The port is } \\
\text { part of an } \\
\text { itinerary; } \\
\text { passengers are } \\
\text { at the port for } \\
\text { only the } \\
\text { duration of } \\
\text { their port call. }\end{array}$ & $\begin{array}{l}\text { At their most basic level, ports of call } \\
\text { require only minimal investment in } \\
\text { services and facilities to accommodate } \\
\text { cruise ships and their passengers. } \\
\text { investment in facilities and services, } \\
\text { including cruise infrastructure. }\end{array}$ & $\begin{array}{l}\text { Acapulco (Mexico) } \\
\text { Bergen (Norway) } \\
\text { Cork (Cobh) Ireland } \\
\text { Darwin (Australia) } \\
\text { St Petersburg (Russia) } \\
\text { Suva (Fiji) } \\
\text { Tauranga (New Zealand) }\end{array}$ \\
\hline $\begin{array}{l}\text { Hybrid } \\
\text { port }\end{array}$ & $\begin{array}{l}\text { Serve as both } \\
\text { home ports } \\
\text { and ports of } \\
\text { call. }\end{array}$ & $\begin{array}{l}\text { Require the same level of investment as } \\
\text { home ports. }\end{array}$ & $\begin{array}{l}\text { Amsterdam (Netherlands) } \\
\text { Bangkok (Thailand) } \\
\text { Auckland (New Zealand) } \\
\text { Singapore } \\
\text { Sydney (Australia) }\end{array}$ \\
\hline
\end{tabular}

Sources: McCalla 1998; McCarthy \& Romein 2012.

Cities new to cruise tourism are likely to establish themselves as ports of call because of the minimal investment required to host cruise ships whilst more established, or mature, ports may seek to promote themselves as home or hybrid ports. Designation as a home or hybrid port is dependent on a wide range of criteria including, for example, proximity to a major international airport; hotel capacity; proximity to source markets; navigational considerations (e.g. availability of tugs, navigational access to the port and distance to the next ports); availability of regulatory personnel such as customs and immigration officials; and the ability to service the ship (e.g. food, fuel and maintenance) (McCalla 1998). However, that designation is increasingly dependent on the city’s ability to promote itself as a desirable home or hybrid port, a challenge which is invariably based on the city’s proven ability to meet the criteria listed above (Lekakou, Pallis \& Vaggelas 2009). Thus, cities new to cruise tourism are unlikely to be able to prove their status as potential home or hybrid ports to the cruise lines. 
Home and hybrid ports generally generate greater revenues for the cruise destination community in the form of pre-and post-cruise accommodation for passengers and crew and additional retail, food, beverage and local transportation consumption (Brida \& Zapata 2010). Cities hosting home ports may also benefit from the higher profile which potentially can accompany investment in tourism-related facilities such as cruise infrastructure (Anttiroiko 2009; Schmalleger \& Carson 2010).

\section{Stakeholders}

Stakeholders who have a legitimate interest in cruise infrastructure development invariably include a diverse array of private and public sector groups and individuals who represent a wide range of interests. They may represent monolithic government organisations, multinational enterprises, central business district, business associations or loose coalitions of local residents or businesses. Their geographical reach may be local, regional, national or international. Thus, the interests represented are likely to be fragmented because of the involvement of the sheer number of divergent interests that are present (McCarthy \& Romein 2012). The capacity to have views heard and indeed, the capacity to make decisions in respect of cruise infrastructure development can on one level be described in the context of power. The challenge is therefore to determine which stakeholders harbour the most power and how those stakeholders exercise and receive that power in the context of proposals for cruise infrastructure development.

Freeman defines stakeholder as "any group or individual who can affect or is affected by the achievement of the organisation’s objectives” (1984, p 46). Yilmaz and Gunel (2009) argue that the phrase, "can affect or is affected by," is sufficiently vague so as to include individuals or groups as stakeholders even without the focal organisation identifying them as such. Other definitions centre on the legitimacy of the stakeholder's claim vis-à-vis an organisation, requiring that the stakeholder has some sort of legal relationship with the organisation such as a contract, legal or moral claim, therefore providing them with the ability (i.e. power) to change the organisation's behaviour (Carroll 1993, in Rowley 1997; Hill \& Jones 1992). However, authors such as Friedman and Miles (2002) reject the view that stakeholders must be legitimate, intimating that little consideration has been given to what distinguishes a legitimate stakeholder from any other class of stakeholder. A different approach is taken by Mitchell, Agle and Wood 
(1997) who identify three attributes that can be used to analyse stakeholder relationships with an organisation, i.e. power, legitimacy and urgency. Together, these traits are used to determine a stakeholder's prominence, or salience. Salience refers to the extent to which a stakeholder is deemed to occupy a position of importance within the decision-making process (Aaltonen \& Kujala 2010), a trait which can be analysed by testing the extent of the stakeholder's power, legitimacy and urgency (Mitchell, Agle \& Wood 1997). Using this approach, a stakeholder can be found to have a legitimate moral or legal claim but no power or alternatively, power but no legitimacy.

\section{The stakeholders}

There are a number of stakeholders who have an interest in cruise destinations or are impacted by the activities related to them. Stakeholders can be divided into four broad categories: cruise line stakeholders, gatekeeper stakeholders, portside stakeholders, and shore-side stakeholders. Examples of stakeholders within each category can be found in Table 3.

Table 3: Stakeholders and their roles

\begin{tabular}{|l|l|}
\hline \multicolumn{1}{|c|}{ Category } & \\
\hline $\begin{array}{l}\text { Cruise industry } \\
\text { Own, operate and manage the } \\
\text { cruise lines, their commercial } \\
\text { relationships and their ships }\end{array}$ & $\begin{array}{l}\text { Shareholders } \\
\text { Executive/management } \\
\text { Ship's company } \\
\text { Cruise passengers } \\
\text { Overarching cruise industry groups }\end{array}$ \\
\hline $\begin{array}{l}\text { Gatekeeper stakeholders } \\
\text { Determine whether it is possible } \\
\text { visit a given cruise destination }\end{array}$ & $\begin{array}{l}\text { Airlines and other long-haul transport providers } \\
\text { Regulatory officials }\end{array}$ \\
\hline $\begin{array}{l}\text { Port side stakeholders } \\
\text { Involved with the ship and }\end{array}$ & $\begin{array}{l}\text { Port owners, operators and management } \\
\text { Cruise terminal owners and operators }\end{array}$ \\
\hline
\end{tabular}




\begin{tabular}{|c|c|}
\hline port and cruise terminal & Ship service providers \\
\hline $\begin{array}{l}\text { Shore side stakeholders } \\
\text { Involved with passengers (and } \\
\text { crew) on-shore, in the destination }\end{array}$ & $\begin{array}{l}\text { Government (national, state and local) } \\
\text { Developers/investors } \\
\text { Inbound tour operators and ground handlers } \\
\text { Destination Management Organisations } \\
\text { Tour and attraction owners and operators } \\
\text { Local transport providers } \\
\text { Local businesses and business organisations } \\
\text { Emergency, health and security providers } \\
\text { Local residents including environmental and other activist } \\
\quad \text { groups } \\
\text { Facilitators (including the media, academics, consultants and } \\
\quad \text { lobbyists) }\end{array}$ \\
\hline
\end{tabular}

\section{Stage of development: proposed, mature and declining cruise destinations}

As in the case of resorts and other land-based destinations (Butler 2006), ports also experience a life cycle comprised of different stages of development. Gui and Russo (2012) propose four life cycle stages: (a) start, (b) growth, (c) maturity, and (d) decline. In this paper, however, we adopt three stages to reflect the lifecycle of cruise infrastructure specifically, i.e. (a) proposed, (b) mature, and (c) declining in order to align with our discussion focusing on proposals for cruise infrastructure development and not during the phase in which a destination begins to develop its cruise tourism industry (i.e. the start phase) These stages are useful in explaining the transformation of cruise infrastructure from its inception to its decline. More significantly, they are used to synthesize how power is exercised between cruise lines and cruise destination stakeholders and amongst the cruise destination stakeholders during each of the three phases. Application of this life cycle model can assist with an understanding of how the cruise lines and cruise destination stakeholders expect to exercise their power and how that power is ultimately exercised in respect of the entrenched power within the cruise destination itself. In other words, the power balance may differ where a new cruise destination seeks to build cruise infrastructure as opposed to a mature destination which seeks to expand its existing cruise infrastructure or where, ultimately, the ships abandon that infrastructure. Following is a discussion of the 
circumstances which may both trigger and influence the exercise of power, based on the cruise infrastructure's stage of development.

Cruise destinations can use or reuse urban land for marine activities (including for the development of cruise infrastructure) that has been deemed to be desirable, capable of attracting investors and potential residents as well as tourists (Doucet et al 2010). Additionally, cruise terminals in particular are often perceived by local policy makers and planners as a means for strengthening a destination's competitiveness in a global environment where competition between cities becomes increasingly intense (McCarthy \& Romein 2012). The redevelopment of waterfront sites and the investment in attractive, efficient and innovative cruise terminals may attract cruise ships, passengers and revenue to the destination; enhance the destination's image (Anttiroiko 2009; Schmalleger \& Carson 2010); potentially attract new service industries into the wider port area; and improve the environmental quality and social well-being for both the city and the surrounding region in the form of development of brownfield industrial sites (McCarthy \& Romein 2012).

However, accompanying these benefits are also a host of costs and disadvantages which are often associated with cruise terminal development, including lower income from cruise operators and visitors than forecast, negative impacts on heritage and historic areas, seasonal employment, waterfront developments tend to benefit visitors rather than local residents etc.

Thus, the exercise of power in the context of cruise infrastructure development will have both its positive and negative consequences, or benefits and risks, respectively. These consequences are likely to have an impact on the negotiations surrounding proposals for cruise infrastructure development.

A mature, or operating, cruise destination may seek to expand its role to that of a turnaround or home port and also re-consider the type of ship it wishes to accommodate and the type of voyage it wishes to attract. Cruise destinations often need to decide what segment of the market they wish to attract (Gui \& Russo 2011), a decision which will, to a large extent, determine the type of ship which they wish to attract. For example, Caribbean itineraries often attract "resort" type 
of passengers who do not get off the ship or only go as far as the cruise lines' private islands (Brida \& Zapata 2010) whilst other ports such as those in New Zealand, South America and Asia generally appear to attract passengers who want to explore new destinations. This bifurcation in the market often governs the type and size of ship that is attracted to the destination. For example, resort-rich mega-ships ply the Caribbean and other mass market type destinations whilst smaller boutique or expedition ships are more suitable for remote locations which cannot be easily visited by large ships.

A cruise destination will generally start to decline when one or more cruise lines abandon that destination. That decline can be experienced at any stage of a cruise destination's stage of development. For example, a destination wishing to attract ships will often build cruise terminals on pure speculation or over-optimistic predictions and then attract only a few or no ships (Murtagh 2011; Peisley 2013). A mature destination may begin to decline when, for example, cruise ships no longer call into that port, on a permanent or shorter-term basis, for any of wide range of reasons. Examples include the Mexican Riviera where for several seasons, threats to cruise passenger security resulted in the large-scale cancellation of port calls and ports in Jamaica and Martinique where passenger complaints over an unregulated taxi industry led to the dropping of those ports (London 2010).

\section{Port characteristics}

There is a host of factors surrounding the ownership, governance, operation and financing of ports which will have varying effects on the power exercised during the negotiations leading to cruise infrastructure development and operation.

\section{Ownership, governance and operation}

A port's profile in terms of ownership, governance and operation is also likely to have an effect on the process followed by cruise infrastructure proposals. Several models of port governance can be identified, each embodying different characteristics with respect to ownership, governance and operation (Di Vaio \& Romana Medda 2010). However, one of the principal differences amongst these models lies in the allocation of the port's functions between the public and private sector. It is the division of ownership, governance and operation between the private and public sectors which may prove to be decisive vis-à-vis a port's role as a major stakeholder. 
In addition, the presence of the cruise lines adds another layer of complexity to the port structure. For example, of the 60 main cruise ports in the Mediterranean and Europe, four are directly operated by cruise lines (Savona, Civitavecchia, Naples and Barcelona) whilst three are partially owned by the cruise lines (Genova, Kusadasi and Tunis) (Di Vaio \& Romana Medda 2010; Gui \& Russo 2011). The remainder of the European cruise ports are operated through private concessions which have been negotiated between the ports and the cruise lines (Gui \& Russo 2011). Elsewhere, for example, Carnival Cruise Lines operates port facilities in Cozumel, Grand Turk, Juneau and Long Beach (California), Naples and Roatan.

Cruise line involvement in the construction as well as the ownership, governance and operation of cruise terminals and related infrastructure (e.g. shipyard facilities) can generate key benefits for the cruise lines. Certainty of tenure in the port (either through outright ownership or the grant of a long-term concession of generally 25 years or more) gives the cruise lines a sufficiently long period of time to develop and implement their passenger handling strategies, including vertically integrating their marine and onshore activities (Gui \& Russo 2011). It also means that the cruise lines can better control their related costs, secure berthing priority for their ships and maintain desired service and quality levels. Upstream integration also means that the cruise lines can assert their power in the investment and management decisions associated with their tenancy and operations in the port, thereby potentially weakening the commercial bargaining capability of the ports. In particular, the cruise lines may seek to invest in or totally fund the cruise terminal in order to control it (Di Vaio \& Romana Medda 2010). However, there can be a significant negative effect for the cruise destination itself. Upstream integration generally forecloses many local businesses from benefitting from the arrival of the ships and their passengers because the cruise lines are likely to entrust their ground handling arrangements to large global companies such as Tui and Kuoni (Gui \& Russo 2011). More significantly, the revenues which are generated through the use of those facilities - including their use by other cruise lines - is for the most part repatriated by the cruise lines offshore, thereby resulting in a potential loss of economic benefit by the local communities.

\section{Co-existence of cruise and commercial shipping}


Cruise ships must often share port infrastructure and facilities with general or commercial ships given the expansive spatial requirements of ports, the need for them to be located in coastal or deep-water locations and the high cost of infrastructure. However, the environment for hosting a general commercial or cargo ship differs significantly for that required by a cruise ship. For example, passengers require comfortable facilities and more specialised services, therefore incurring additional costs for ports. Therefore, both the port and the cruise lines are likely to assert their power in the commercial negotiations required to secure infrastructure suitable for cruise passenger use.

\section{Type of cruise infrastructure}

Cruise infrastructure can range from providing access to a general purpose wharf positioned on publicly-accessible foreshore to an architecturally-designed, amenity-rich terminal. Cruise ships may also share ferry berths and facilities or use a variety of terminals and wharves in any given port, depending on the size of the cruise ship, the number of other cruise ships in port on any given day and the size of the ship.

\section{Changes in port operations and competitiveness}

Changes in port operations have an impact on itinerary planning and cruise destination choice. Whilst the trend towards centralising port operations and re-allocating services between ports largely affects commercial shipping, cruise ships using those ports are affected. Di Vaio and Romana Medda argue that ports wishing to continue to service cruise ships will need to demonstrate high levels of service quality in order to ensure that the cruise lines continue to visit their ports, that "[t]he competitive advantage of a port usually correlates to its infrastructure characteristics, and certainly this influences the choice and definition of the routes” (2010, unp). This reorganisation has resulted in ports which are facing a decline in their commercial shipping to build cruise infrastructure to provide them with an additional revenue stream.

\section{Origin of the proposal}

A destination's decision to pursue development as a cruise destination can arise from (a) the destination seeking to engage in cruise tourism; or (b) from a cruise line approaching the destination. Determination of the origin of the decision or proposal to become a cruise 
destination is significant because the analysis of power amongst cruise destination stakeholders will in large part turn on whether it is the cruise lines who approach the cruise destinations or whether the cruise destinations approach the cruise lines. This factor is likely to have a significant impact on the power balance amongst the stakeholders, often being decisive in relation to such variables as how the cruise facilities are financed, how the terminal space will be used (i.e. whether it will be multi-use or single use) and who will own and operate the terminal.

Thus, the nature of the exercise and receipt of power with respect to proposals for cruise infrastructure development is likely to depend on a wide range of factors which affect the stakeholders who are directly or indirectly involved in that development. As discussed in this section, those factors may arise from such characteristics as the type of port, the affiliation or interest of the relevant stakeholders, the cruise destination's stage of development, the commercial profile of the port and the origin of the proposal for cruise infrastructure development. In the next section, we discuss these characteristics in the context of several reported cases concerning the processes leading to proposals for cruise infrastructure development and in many cases, the result of such proposals.

\section{The expression of power: cruise line - cruise destination engagement}

The motivation for that research can be found in the cases which follow, namely, the emergence of power in stakeholder interaction with respect to proposals for cruise infrastructure and the headline results of those expressions of power. The cases have been chosen on the basis of reports in the general and specialised cruise industry media. Their fact patterns form the basis for empirical research, which is currently being undertaken (albeit in other destinations), research which includes surveys directed to and interviews involving relevant stakeholders. In other words, the cases discussed in this paper are not meant to provide a detailed analysis of individual stakeholder perceptions of the operation of power, but to begin to identify the issues, which will be considered in greater depth in our empirical research. Newspaper reports have been found to be an important tool in uncovering the sources and expression of conflict among stakeholders in relation to major tourism infrastructure projects (Markwick 2000). The reporting of the cases described in this paper, often occupying substantial space in the media, can itself be considered indicative of the importance, emotion and hence, the expressions of power, which the investment 
in cruise infrastructure can generate. The cases have been selected to reflect a variety of scenarios initially based on whether it is stakeholders within the destination who initiate the proposal for cruise infrastructure development or the cruise lines. We also identify some of the increasingly significant political, economic and social issues facing cruise destinations, issues that form a significant part of our empirical research. These issues go beyond ships and ports involving, for example, governments undertaking policy decisions, communities managing the impacts of cruise tourism and investors seeking a return on their investment. Each of these stakeholders will assert power.

\section{A tale of two American turnaround cities - Mobile, Alabama and Houston (Bayport), Texas}

The promise of jobs and other economic benefits motivated the city of Mobile, Alabama to build a cruise terminal, ostensibly “in partnership” with Carnival Cruise Line (CCL) (Murtagh 2011). The decision to build was triggered when CCL announced in November 2001 that it would operate three cruises from Mobile deploying its small ship, Holiday, and that if those cruises were successful, it would consider more voyages (Drobnic 2001). The city acted on the statement, and in 2004 built a cruise terminal that was initially funded by the state retirement system, but which was later bought out by the city, which then operated the terminal on its own. Soon thereafter, Holiday was replaced by the larger Elation, generating significant revenues for the city. However, in 2011, CCL relocated Elation to the nearby port of New Orleans, citing insufficient revenues and rising fuel prices. The move left the City of Mobile with a US $\$ 30$ million debt (Murtagh 2011). An almost identical situation occurred in Bayport (Houston), Texas, where the city built a new cruise terminal at a cost of US\$108 million, financed through a bond issue (debt financing) (Peisley 2013). A few ships called into Bayport in 2008 when ships were diverted from Galveston by Hurricane Ike, and in 2011, CCL pulled out of Bayport entirely (Peisley 2013). There is some doubt, however, as to whether CCL's reasons for leaving Mobile were in fact its real reasons. One industry expert commented that as the domestic US market becomes more competitive owing to cruise lines relocating their ships overseas, not enough was or is being done to promote Mobile as a potential home port or destination (FoxNews.com 2012). However, at the date of this writing (February 2014), the city claims to be close to securing another ship, but doubts have surfaced as to whether this effort will be successful. These doubts 
turn on Mobile's proximity to more popular ports such as New Orleans, the limited scope for ships sailing out of Mobile to cruises in the Western Caribbean (Sharp 2013) and the lack of promotion of Mobile’s attractions to cruise passengers (FoxNews.com 2012).

Both Mobile and Bayport represent examples of destinations eager to partake in cruise tourism's economic benefits, relying on non-binding agreements in their relationships with the cruise lines to attract ships. Both cities used public monies to build their terminals, and both were left servicing large amounts of debt (Moreno 2011; FoxNews 2012). Each is now offering incentives to the cruise lines to attract their ships. In the case of Mobile, the city is seeking to redress the situation by offering incentives such as free advertising to a cruise line with which it is negotiating and free tickets to a local museum for its passengers (FoxNews.com 2012), but neither of these incentives would appear to be capable of achieving their objective of securing a long-term, sustainable relationship. In contrast, in 2013, Bayport offered substantial financial and operational incentives to both Princess Cruise Lines (PCL) and Norwegian Cruise Lines (NCL) in exchange for commitments to use the Bayport Terminal (Collier 2012).

The incentives offered by Houston with respect to its Bayport terminal have met with political opposition, despite the fact that the city would otherwise be left with an abandoned cruise terminal, a high debt to service, ongoing maintenance costs of about US\$500,000 a year and loss of expected economic benefits. While US\$6 million was spent, the city defends its position, stating that a commissioned study shows that the city's economic gain from the two cruise lines' port calls would be US\$200 million, a sum which the city has earmarked for economic growth (Peisley 2013). However, incentives are often criticised by opposing political interests, arguing that those incentives are, in effect, subsidising the cruise lines, a view held by some Houston politicians and a state senator (Peisley 2013).

Another issue with political undercurrents has also been articulated with respect to the offering of incentives by Bayport. A state legislator has claimed that the neighboring port of Galveston will experience a reduction in its cruise traffic because of the more favorable terms being offered by the City of Houston (Peisley 2013). Whether the granting of incentives by one port does in fact negatively impact another port is a difficult matter to analyse with any certainty. While 
substantial incentives will almost always be highly attractive, the sheer competitiveness and global nimbleness of the cruise industry undermine this argument. As noted above, the City of Mobile's offer of incentives has been deemed to be inadequate to promote Mobile as a potential home port or destination because of the cruise lines' strategy of relocating their ships to their most lucrative markets, markets which may be overseas (FoxNews.com 2012).

Thus, there are substantial risks for cities which want to attract cruise ships and as a result, build cruise terminals on pure speculation, relying on pre-contractual, non-binding discussions with cruise lines which may or may not ultimately be attracted to that city. Those risks generally tend to be exacerbated where the cruise lines are not required to make a financial or management investment in the cruise facilities and also where political conflict arises.

\section{A tale of two Australian ports-of-call cities - Darwin (Northern Territory) and the Gold Coast (Queensland)}

A different fact pattern is present in the Darwin cruise terminal controversy, but nonetheless, conveys sentiments of power and conflict. Darwin is the capital city of the Northern Territory (NT) on the north coast of Australia. It is a small city of approximately 130,000 residents and is Australia's only tropical capital city. The NT government views tourism as a significant industry, and accordingly invests heavily in its development (Schmallegger \& Carson 2010). In 2008, the city opened its A $\$ 5.5$ million cruise terminal which forms part of the city’s flagship waterfront development. Part of the rationale for its construction was to increase the number of visitors to Darwin, particularly during the months when cruise ships would visit, thereby addressing issues of seasonality (Schmallegger \& Carson 2010). Another objective articulated by the NT government was the creation of jobs. However, it became apparent that the jobs created were not long term but related only to the terminal's construction and not to sustainable job creation (Schmallegger \& Carson 2010). Two of the prominent issues in this development are the local community's perception that it was not consulted by the territory government and that the territory government may have put its own objective of increasing visitor numbers ahead of creating a sustainable economy based on tourism in the city itself. In other words, the NT government was seen to be engaging in "boosterism" (Schmallegger \& Carson 2010). A further issue is the Darwin Port Corporation's (DPC) view that while the new terminal can 
accommodate the current fleet of large cruise ships, it will not be able to accommodate larger ships with increased numbers of passengers and crew without upgrading the wharf area (Darwin Port Corporation 2011). While Darwin's cruise tourism sector is growing (Tourism NT 2012), it is evident that the NT government's goal of increasing the number of visitors to the city has alienated a wide range of stakeholders in the city. For example, some business owners have protested that the new waterfront facilities do nothing to attract visitors into the city itself (Schmallegger \& Carson 2010).

Community consultation, environmental activism and political will were also headline issues in both the 2006 and 2014 demise of cruise terminal proposals on the Gold Coast (Queensland) (Ardern \& Harbour 2014; Berkman 2012). In December 2005, the state-established Gold Coast Marine Development Board tabled a proposal for a cruise terminal and other marine facilities to be built at The Spit (Dredge 2010), a favorite coastal area for residents, tourists, surfboarders and environmentalists. However, the proposal was withdrawn in August 2006 (Berriman 2013), just one month before a well-organised community protest took place and a month prior to State government elections. The remit of the Board was to prepare the Environmental Impact Statement (EIS) and "provide advice back to the State government" (Queensland Government 2005). As a state-created agency, criticism was levelled at the Board because it was dominated by “developers, consultants, economic development officers and engineers," with only one board member representing community interests (Dredge 2010, p 110). Also, by taking control of the process (including drafting the EIS), it was felt that the Board wrested decision-making control from the local community (Dredge 2010), a situation not dissimilar to that experienced in Darwin (Schmallegger \& Carson 2010). The state government justified its actions by attributing its plans for a cruise terminal to Queensland's Cruise Shipping Plan (Dredge 2010), with the objectives of positioning Queensland as a unique tourism destination and enabling the state to reap substantial direct and indirect economic and other benefits (Tourism Queensland 2006).

Withdrawal of the 2005/2006 proposal did not prevent other proposals from being tabled. In 2012, a wealthy developer submitted a proposal to build a cruise terminal at Kirra Beach (Bilinga), 30 kilometres south of The Spit as part of a privately financed waterfront complex which would also include hotels, a casino, shops and restaurants (Stolz 2013). One objective of 
the complex was to enable the foreign developer to secure a casino licence. In December 2013, it appeared that the complex would go ahead (Berriman 2013). However, local residents and environmental and surfboarding groups protested, citing Kirra Beach’s world-class surf-break and The Spit's environmental significance (Ardern \& Harbour 2014). In January 2014, the Queensland premier definitively rejected the proposal because of its potential damage to the beach and its surfbreak (Australian Associated Press 2014). He was also quoted as stating that other proposals for a cruise terminal further south at Broadwater were also not likely to succeed (ABC News 2014). However, just a month later (February 2014), the Queensland government approved a design submitted by a Chinese consortium for the terminal at Broadwater (Stephens 2014; Willoughby \& Ardern 2014). Interestingly, the Kirra Beach proposal was welcomed by Carnival Australia who stated that two of its ships would call into the proposed Gold Coast terminal as long as the approach to the terminal was adequately dredged (Carnival Australia 2012; Berriman 2013).

\section{The Western Mediterranean: Barcelona - a mature, turnaround port}

Barcelona, Spain represents an example where a cruise line has negotiated with a mature port to obtain security in their use of port facilities. This security usually takes the form of a long concession (e.g. 25 years or more), giving the cruise line ample time to pursue its strategic goals with respect to that destination, control its supply chain, secure priority berthing arrangements and guarantee its desired levels of quality and customer service (Gui \& Russo 2011). In the case of Barcelona, the Costa Cruise Terminal (Palacrusieros) was built as the result of an agreement between the Barcelona Port Authority and Costa Crociere, a brand of Carnival Cruise Lines (Port of Barcelona 2013a). The terminal was entirely financed by Costa Crociere SpA (Port of Barcelona 2013b). In this case, the deal was negotiated and concluded on a strictly commercial basis and did not involve any community or peripheral stakeholders. Significantly, this terminal is one of seven cruise terminals at the Port of Barcelona (Barcelona 2013a), which is a mature, urban, year-round home port and cruise destination. Therefore, no significant level of risk appears to be involved.

\section{The Western Caribbean - the Cayman Islands}


The Cayman Islands are located in the Western Caribbean, approximately $240 \mathrm{~km}$ south of Cuba and $740 \mathrm{~km}$ south of Miami, Florida (Government of the Cayman Islands 2011). The islands already attract cruise ships but because of the lack of berthing facilities, ships moor in the harbor. In a bid to attract more cruise ships as well as to accommodate mega-ships, the Cayman Islands government proposes to build a cruise terminal and two new piers so that passengers do not have to be tendered to shore (Government of the Cayman Islands 2013). The government seeks to finance the US\$300 million project through a public-private partnership (PPP) (Robbins 2011), relying on the cruise lines to cover at least the cost of the piers (Major 2013b; Whitaker 2014). In this case, the rationale for adopting a PPP approach is specifically to avoid public debt if the terminal is not used as anticipated. While this stated objective incorporates an astute risk management strategy, the government is also imposing two additional conditions in order to manage the potential risks. In contrast to Barcelona where a cruise line has secured control of a cruise terminal within the port, the Cayman Islands government has mandated that despite the requirement that a cruise line invest in the new facilities, control of the facilities will be retained by the Port Authority (Major 2013a). In addition, the government has excluded any shore-side retail development from the project so as not to affect local businesses that would otherwise be financially impacted (Whitaker 2013). Interestingly, the current talks between the government and the cruise lines emphasise the cruise line as the user of the facilities and not as a partner or participant (Whitaker 2014). In other words, the talks are addressing specific operational requirements.

The basis for the Cayman Islands decision has been questioned by an industry critic who believes that the Islands' proximity to Cuba will threaten the Islands as a port of call once Cuba becomes a regular cruise destination. However, the Grand Cayman Tourism Minister believes that more ships will visit Grand Cayman as part of itineraries that include Cuba.

\section{Falmouth, Jamaica - a very colonial port}

While a city aspiring to become cruise destinations may approach the cruise lines with incentives to attract their ships, there are instances where the cruise lines may approach the city. Royal Caribbean Cruise Lines (RCCL) approached the town of Falmouth, proposing that if the port would commit to spending US\$122 million to deepen its port and construct a facility which 
could accommodate two mega-ships simultaneously (for a total project cost of US\$224 million (The Gleaner 2008), RCCL would use Falmouth for its Genesis class ships, Oasis of the Seas and Allure of the Seas (Kerswill 2013), both of which have a double-occupancy capacity of 5,400 passengers and a maximum occupancy capacity of 6,360 passengers (Cruise Critic 2014a; Cruise Critic 2014b). In exchange, RCCL guaranteed the port 400,000 passengers per year over the next four years (Jamaica Information Service 2008). Notably, RCCL did not guarantee a minimum spend over that time. Falmouth is now the largest purpose-built port of call in the Caribbean, with the capacity to handle 16,000 passengers and an arrivals area designed to accommodate 4,000 passengers at any given time (Kerswill 2013). The Falmouth pier is the responsibility of the Port Authority of Jamaica in partnership with RCCL (PR Web 2011) and according to the president of the Port Authority of Jamaica, no equity stake in the facilities is accorded to RCCL (The Gleaner 2008).

The siting of the new port facilities created some dislocation and disruption to existing properties and also resulted in the relocation of public transport to allow for a pedestrian route to and from the cruise terminal. Thus, despite RCCL's assurances that the town would benefit economically from hosting RCCL’s Genesis class mega-ships, the reality appears to be different. Some tourism businesses near the port benefited (Kerswill 2013), but the town's businesses have not realised the gains they had anticipated because, for example, passengers are driven by coach for shore excursions to Ocho Rios or Montego Bay and tend to patronise internationally recognised shops rather than local ones (Elliott 2011; Royal Caribbean Cruise Lines (RCCL) 2011; The Gleaner 2011). Headlines from local news reports and even RCCL’s own blogs report similar comments, i.e. that the ships tower over the town; that the Allure of the Seas has more passengers than there are residents in the town; and that the ship will return to Miami with millions of dollars destined for the company, with little flowing into the town (The Gleaner 2011; The Gleaner 2012).

A summary of the cases reported above according to the framework proposed in this paper is presented at Table 4. It illustrates various examples of the complex dynamic that exists for the exercise of power in regards to the type of port, dominant stakeholders, stage of development, port characteristics and the initiator of the proposal. 
Table 4: Summary of reported cases

\begin{tabular}{|c|c|c|c|c|c|}
\hline Case & $\begin{array}{l}\text { Type of } \\
\text { port }\end{array}$ & $\begin{array}{l}\text { Dominant } \\
\text { stakeholders }\end{array}$ & $\begin{array}{l}\text { Stage of } \\
\text { development }\end{array}$ & Port characteristics & $\begin{array}{l}\text { Initiator of the } \\
\text { proposal }\end{array}$ \\
\hline $\begin{array}{l}\text { Mobile, } \\
\text { Alabama }\end{array}$ & Turnaround & $\begin{array}{l}\text { City Council } \\
\text { Cruise line }\end{array}$ & $\begin{array}{l}\text { New } \\
\text { (declining) }\end{array}$ & $\begin{array}{l}\text { Dedicated cruise } \\
\text { terminal constructed }\end{array}$ & $\begin{array}{l}\text { City Council, on } \\
\text { strength of } \\
\text { announcement that } \\
\text { Carnival would } \\
\text { operate cruises from } \\
\text { Mobile. }\end{array}$ \\
\hline $\begin{array}{l}\text { Bayport } \\
\text { (Houston } \\
\text { )Texas }\end{array}$ & Turnaround & $\begin{array}{l}\text { City Council } \\
\text { Cruise line }\end{array}$ & $\begin{array}{l}\text { Mature } \\
\text { (declining) }\end{array}$ & $\begin{array}{l}\text { Dedicated cruise } \\
\text { terminal constructed }\end{array}$ & $\begin{array}{l}\text { City Council, on } \\
\text { strength of goal of } \\
\text { permanently capturing } \\
\text { cruise traffic diverted } \\
\text { to Bayport from } \\
\text { Galveston following } \\
\text { Hurricane Ike }\end{array}$ \\
\hline $\begin{array}{l}\text { Darwin, } \\
\text { Australia }\end{array}$ & Port-of-call & $\begin{array}{l}\text { State government } \\
\text { City Council } \\
\text { Port corporation } \\
\text { Local residents } \\
\text { Local business } \\
\text { community }\end{array}$ & Mature & $\begin{array}{l}\text { New cruise terminal } \\
\text { to replace older one } \\
\text { Part of waterfront } \\
\text { development, also } \\
\text { including a new } \\
\text { convention centre }\end{array}$ & $\begin{array}{l}\text { State government, in a } \\
\text { bid to boost tourism }\end{array}$ \\
\hline $\begin{array}{l}\text { Gold } \\
\text { Coast, } \\
\text { Australia }\end{array}$ & Port-of-call & $\begin{array}{l}\text { State government } \\
\text { Gold Coast } \\
\text { Marine } \\
\text { Development } \\
\text { Board } \\
\text { Local } \\
\text { residents/activist } \\
\text { groups }\end{array}$ & Proposed & $\begin{array}{l}\text { Recreational } \\
\text { waterfront land with } \\
\text { no prior cruise or } \\
\text { commercial port use }\end{array}$ & $\begin{array}{l}\text { State government in a } \\
\text { bid to transform the } \\
\text { state into a "unique” } \\
\text { tourism development. }\end{array}$ \\
\hline
\end{tabular}




\begin{tabular}{|l|l|l|l|l|l|}
\hline aarcelon & Hybrid & $\begin{array}{l}\text { Cruise lines } \\
\text { Port authority }\end{array}$ & Mature & $\begin{array}{l}\text { Dedicated, } \\
\text { expanding cruise } \\
\text { port }\end{array}$ & $\begin{array}{l}\text { The cruise line, in } \\
\text { agreement with the } \\
\text { port authority }\end{array}$ \\
\hline $\begin{array}{l}\text { Cayman } \\
\text { Islands }\end{array}$ & Port-of-call & $\begin{array}{l}\text { Cayman Islands } \\
\text { government } \\
\text { Cruise lines }\end{array}$ & Mature & $\begin{array}{l}\text { No dedicated or } \\
\text { landside cruise } \\
\text { facilities; passengers } \\
\text { are tendered to shore }\end{array}$ & $\begin{array}{l}\text { Cayman Islands } \\
\text { government, with } \\
\text { strict conditions } \\
\text { attached }\end{array}$ \\
\hline $\begin{array}{l}\text { Falmout } \\
\text { hamaica }\end{array}$ & Port-of-call & $\begin{array}{l}\text { Cruise line } \\
\text { Port Authority }\end{array}$ & Mature & $\begin{array}{l}\text { Existing cruise port, } \\
\text { re-developed as the } \\
\text { largest purpose-built } \\
\text { port of call in the } \\
\text { Caribbean }\end{array}$ & $\begin{array}{l}\text { Royal Caribbean } \\
\text { Cruise Line, on } \\
\text { condition that the port } \\
\text { commit to substantial } \\
\text { investment }\end{array}$ \\
\hline
\end{tabular}

\section{Discussion and conclusions}

These case studies illustrate the inherent complexities of power in relation to proposals for the development and management of cruise infrastructure. Power and the risks which can arise from the exercise of power can emanate from any stakeholder. For example, although the ultimate expression of power in this context is thought to lie with the cruise lines because of their ability to move their ships around at will, stakeholders within cruise destinations also exercise significant power. Examples include the assertion of power by community groups who successfully protest against proposals to construct cruise terminals (Ardern \& Harbour 2014) and the ability of city officials in Houston, Texas to attract cruise ships to the city's abandoned cruise terminal through the grant of generous incentives to the cruise lines despite political opposition (Collier 2012; Peisley 2013). The case studies also demonstrate the exercise of power at different stages of a cruise destination's development, highlighting various situations depending on whether it is the cruise line or the cruise destination which initiates the proposal for cruise infrastructure. 


\section{The exercise of power - the key stakeholders}

The cruise lines

As noted above, one way cruise lines exercise power is by choosing to call into a port, or not. However, given that itineraries and their cruise destinations continue to be central to passengers' cruise tourism experience, cruise lines will also seek to exercise their power in their commercial relationships within the cruise destination. Two of the examples discussed earlier in this paper illustrate how this power may be exercised: security of the ships' berthing priority and security of the cruise lines' supply chain (Di Vaio \& Romana Medda 2010). In both instances, the cruise lines may achieve these objectives by negotiating long-term concessions with the port or taking a full or partial ownership stake in the cruise facilities (Gui \& Russo 2011; Port of Barcelona 2013a). The ability to control both pier access and suppliers such as ground handlers and tour operators not only places cruise lines in a dominant position with respect to a given port, but it also guarantees the port the security of a long-term tenant who will invest in the required infrastructure.

\section{The ports}

Cruise destinations seeking to reap the economic benefits of cruise tourism may approach the cruise lines or be approached by them. In the first instance, though, commercial negotiations will take place with the port with respect to the potential for or the availability of existing cruise infrastructure. However, because cruise shipping is not core business for most ports, cruise ships can be viewed as unwelcome visitors given, for example, the high expenditure required to ensure that passengers can disembark into a comfortable environment, the threat or disruption cruise ships can cause to the ports’ more lucrative commercial shipping business (Bromby 2013) and the incentives which may favor cruise ships (Peisley 2013).

However, Darley (2011) argues that port authorities can do significantly more to assert their power, mitigate risk and grow their commercial interests. He urges them to shed their "bureaucratic processes and limited vision" and become "[less] cautious in dealing with what is perceived as onerous cruise lines positions when it comes to incorporating or planning for cruise passenger service” (Darley 2011, unp). He cites Falmouth as a port which is exploiting its commercial potential through sustainable real estate models rather than relying on an outdated 
business model. Darley effectively argues that commercial ports should not succumb to the cruise lines or put those relationships in the "too-hard basket," but instead work with the cruise lines to extend their revenue activities beyond the two traditional functions of handling and service fees (Darley 2011). Interestingly, although a whole tourism "village" has been constructed within the port area at Falmouth (Kerswill 2013), retail space has been explicitly excluded from the Cayman Island's proposed cruise terminals (Whitaker 2013). It will be interesting to see how the cruise lines react to the Cayman Islands' conditions in a cruise market (i.e. the Caribbean) where the cruise lines have traditionally controlled the development and operation of cruise ports, approaching governments to develop ports viewed as strategic by the cruise lines (Darley 2012b). One of the negative impacts of this model is indeed being felt by the Port of Falmouth: the port itself benefits from the improvement to the port but very little additional revenue trickles into the community (Darley 2012a).

The suggestion that ports adopt a more commercial stance toward cruise shipping is also reflected in comments by the CEO of Ports Australia who stated that the cruise lines should work more closely with the ports or risk losing out to the ports' commercial shipping interests, particularly where ports are privatised (Bromby 2013). This need for collaboration will also be a factor for ports that are experiencing changes to their port operations. While largely involving commercial shipping, the trend towards centralising port operations and reallocating services between ports will also affect cruise ships using those ports. Ports wishing to continue to service cruise ships will need to demonstrate high levels of service quality to ensure that cruise ships continue to visit their ports, since "[t]he competitive advantage of a port usually correlates to its infrastructure characteristics, and certainly this influences the choice and definition of the routes" (Di Vaio \& Romana Medda 2010, unp). In other words, where shipping services are centralised or reallocated among ports, cruise shipping services will need to be continued at every port hosting cruise ships.

\section{The community}

Communities are undeniably affected by the power of cruise lines which are likely to be based in cities far from the destinations their ships visit (Brida \& Zapata 2010; Hritz \& Cecil 2008). However, as the case studies illustrate, power also lies in the community and within groups of 
stakeholders within the community including the government, the business community and local residents. Within cruise destinations, groups of local residents can exercise their power to challenge the development of cruise terminals as on the Gold Coast (Ardern \& Harbour 2014) and also to express their power sufficiently to compel changes to existing or planned uses, as in Venice (Reuters 2013). These two particular cases are also interesting because community power proved to be successful in both a proposed cruise destination and a mature one. In the case of the Cayman Islands, the government is asserting its power to exclude retail space from the proposed new terminal that it expects to be funded in partnership with the cruise lines (Whitaker 2013). In this case, this exclusion can be viewed as potentially inconsistent with the cruise lines’ own objectives of deriving revenue from a facility in which they will have an interest.

Another assertion of cruise destination, or community, power is the granting of incentives to the cruise lines to attract their ships. In the case of Bayport (Houston), the City Council owners of an abandoned cruise terminal successfully attracted two major cruise lines back to the city (Peisley 2013) while incentives granted by the New South Wales (Australia) government are credited with triggering the current boom in Sydney's already mature cruise tourism market (Bromby 2013). Both cases have evoked criticism of the granting of incentives. Bayport's incentives met with political opposition from dissenting council members while the nearby, thriving port of Galveston faced the more specific potential threat of a reduction in cruise traffic (Peisley 2013). However, in the case of Bayport, the issue may in fact be Galveston's increasing lack of ability to compete. Whilst Galveston has been a popular cruise port, most of the passengers embarking from Galveston are from the Houston area where the new Bayport terminal is large with convenient parking (as opposed to Galveston where parking is off-site, requiring transfers by shuttles). Also, Bayport has plenty of room to expand at low development costs, thereby potentially enabling the port to offer lower fees or more incentives to the cruise lines (Galveston Cruise Tips 2014).

However, Galveston offers cruise lines lower fuel costs for trips to the Caribbean because of its proximity to the Gulf of Mexico and the benefit of its experience in working with the cruise lines. Furthermore, Galveston is popular with passengers because of its own attractions for 
visitors (Galveston Cruise Tips 2014). Therefore, while incentives may be considered to be an expression of a cruise destination's power, counterbalancing effects may come through responses of local taxpayers (arguing that incentives are actually subsidies) and manifestations of competition such as passenger preference and lower operating costs.

\section{Conclusions}

The case studies presented in this paper identify many of the key stakeholders and interests present in proposals for and the development and operation of cruise infrastructure in a wide range of cruise destinations. They also demonstrate the power underpins the commercial relationships among stakeholders as well as some of the risks which can arise as a result of those relationships. The case studies show that the analysis of the power that exists among stakeholders cannot be considered in isolation, but instead must be considered alongside the issues which affect those relationships.

Given the wide range of issues and their complexity, it is useful to undertake any analysis within the guidelines of the framework outlined in this paper: (a) the origin and interests of the stakeholders; (b) whether the cruise lines have approached the cruise destination or vice versa; and (c) the cruise destination's stage of development. This framework provides the means for cities to evaluate the potential for development or expansion of their cruise infrastructure as well as the risks which can attach. Such an analysis becomes critical as cruise destinations are faced with decisions regarding their short-, medium- and long-term planning with respect to cruise infrastructure, particularly where ports need to divert resources away their commercial shipping activities to service cruise ships which often do not generate as much revenue for those ports, and where the popularity of cruising motivates many cities to develop cruise infrastructure on the pure speculation that the ships will come.

Understanding the dynamics of power in stakeholder inter-relationships can also assist cruise destinations to determine the best method of financing new cruise infrastructure as a way to mitigate potential risks. For example, opting for a public-private partnership financing model which includes at least some investment from one or more cruise lines may reduce the possibility that the cruise lines will walk away from that cruise destination. Also, investment by the port in 
a multi-use facility can address issues of seasonality and more significantly, generate other sources of revenue for the port. In each of these situations, the cruise destination will require a clear understanding of the extent of the investment required (a factor which may depend on the cruise destination's stage of development); the vested interests of the stakeholders who are affected; and who has approached whom with the proposal to develop cruise infrastructure. All of these factors must be considered in the context of an oligopolistic, deterritorialised industry which is likely to be based far from its cruise destinations, thereby potentially heightening the criticisms and fears of stakeholders within those cruise destination.

Whilst it is beyond the scope of this paper to discuss or even enumerate all of the potential expressions of the exercise of power in the context of cruise infrastructure and the potential risks which can accrue, it is evident that as cruise tourism grows, power will be manifested in different ways. Therefore it is important to understand how power operates so that commercial negotiations among cruise destination stakeholders and with the cruise lines can be undertaken in the most favorable way possible. 


\section{References}

ABC News 2014, "Queensland Premier Campbell Newman to reject Gold Coast beach casino bids,” ABC News, 20 January, http://www.abc.net.au/news/2014-01-20/newman-rules-out-beachcasino-bids/5208052 (Retrieved 12 February 2014).

Anttiroiko, A-V. (2009) Urban Responses to Global Intercity Competition. In: Kultalahti, J. \& Karppi, I. \& Kultalahti, O. \& Todisco, E. (Eds.) Globalisation: Challenges to Research and Governance, pp. 257-279. Helsinki: East-West Books.

Ardern, L \& Harbour, J 2014, “Premier Campbell Newman kills off Bilinga cruise ship terminal plan,” Gold Coast bulletin, 16 January, http://www.goldcoastbulletin.com.au/lifestyle/beachesand-fishing/premier-campbell-newman-kills-off-bilinga-cruise-ship-terminal-plan/storyfnk744sw-1226802675065 (Retrieved 6 February 2014).

Australian Associated Press 2014, “Campbell Newman rules out \$2bn cruise ship terminal on Gold Coast,” theguardian.com, 16 January, http://www.theguardian.com/world/2014/jan/16/campbell-newman-rules-out-2bn-cruise-shipterminal-on-gold-coast (Retrieved 9 February 2014).

Berkman, K 2012, “Critics say Gold Coast plan for cruise ships won’t float,” ABCNews.com, 3 August, ABC News, Queensland, http://www.abc.net.au/news/2012-08-03/critics-say-goldcoast-plan-for-cruise-ships-wont/4176236 (Retrieved 18 February 2014).

Berriman, J 2013, “Gold Coast cruise terminal to go ahead,” cruise1st.com.au, http://news.cruise1st.com.au/cruising/gold-coast-cruise-terminal-to-go-ahead/ (Retrieved 18 February 2014).

Bohrer, B 2010, “Alaska cruise ship head tax cut approved,” NBCNews.com, 15 April, NBCNews.com, New York, http://www.nbcnews.com/id/36465517/ns/travel- 
cruise_travel/t/alaska-cruise-ship-head-tax-cut-approved/\#.VDzla_mSxIE (Retrieved 14 October 2014).

Brida, J \& Zapata, S 2010, “Cruise tourism: economic, socio-cultural and environmental impacts,” International journal of leisure and tourism marketing, vol 1 no 3 pp 205-226.

Bromby, R 2013, “Cash call as ports fear being swamped by cruising,” The Australian, 8 November,http://www.theaustralian.com.au/business/in-depth/cash-call-as-ports-fear-beingswamped-by-cruising/story-fnjy4qn5-1226754955765 (Retrieved 14 December 2013).

Butler, R. (Ed.). (2006). The tourism area life cycle (Vol. 1). Channel View Publications, Clevedon.

Carnival Australia 2012, “Carnival Australia welcomes initiative on Gold Coast cruise terminal,” Media release, 11 November, http://www.carnivalaustralia.com/mediareleases/2012/november/carnival-australia-welcomes-initiative-on-gold-coast-cruiseterminal.aspx (Retrieved 6 February 2014).

Carroll, A 1993, Business and society, South-Western, Cincinnati, in Rowley, T 1997, “Moving beyond dyadic ties: a network theory of stakeholder influences,” Academy of management review, vol 22, no 4, pp 887-910.

Charlier, J \& McCalla, R 2006, "A geographical overview of the world cruise market and its seasonal complementarities," in Dowling, R ed, Cruise ship tourism, pp 18-30, CABI, Wallingford.

Cheong, S \& Miller, M 2000, “Power and tourism: a Foucauldian observation,” Annals of tourism research, vol 27, no 2, pp 371-390.

Chin, C 2008, Cruising in the global economy: profits, pleasure and work at sea, Ashgate, Hampshire. 
Clancy, M 2008, “Cruisin' to exclusion: commodity chains, the cruise industry, and development in the Caribbean," Globalizations, vol 5, no 3, pp 405-418.

Clegg, S 1989, Frameworks of power. Sage, London.

Coles, T \& Church, A eds 2007, Tourism, power and space, Routledge, London.

Collier, K 2012, “Port will pay \$6.7 million to lure two cruise lines,” Houston Chronicle, 19 November, Houston Chronicle , Houston, http://www.chron.com/business/article/Port-will-pay6-7-million-to-lure-two-cruise-4051674.php (Retrieved 17 February 2014).

Cornwell, A 2013, “UAE expanding port facilities for cruise ships,” Gulfnews.com, 7 December, http:/gulfnews.com/business/tourism/uae-expanding-port-facilities-for-cruise-ships-1.1264333 (Retrieved 17 February 2014).

Cruise Critic 2014a, “Allure of the Seas review," CruiseCritic.com, The Independent Traveler Inc, Pennington, http://www.cruisecritic.com/reviews/review.cfm?ShipID=530 (Retrieved 6 February 2014).

Cruise Critic 2014b, "Oasis of the Seas review," CruiseCritic.com, The Independent Traveler Inc, Pennington, http://www.cruisecritic.com/reviews/review.cfm?ShipID=368 (Retrieved 6 February 2014).

Cruise Line International Association (CLIA) 2014, Press release - US cruise industry saw continued growth, economic contributions in 2013, 15 September, CLIA, Washington, http://cruising.org/regulatory/news/press_releases/2014/09/us-cruise-industry-saw-continuedgrowth-economic-contributions-2013 (Retrieved 2 October 2014).

Cruise Market Watch 2014, "Growth of the cruise line industry,” Cruise Market Watch, http://www.cruisemarketwatch.com/growth/ (Retrieved 7 February 2014). 
Darley, H 2011, “Economic growth: revenue streams for port authorities,” Hugh Darley’s Blog, 18 July, http://hughdarley.wordpress.com/2011/07/18/economic-growth-revenue-streams-forport-authorities/ (Retrieved 16 January 2014).

Darley, H 2012a, "Front door of tourism - building destinations, not just piers," Hugh Darley's Blog, 15 September, http://hughdarley.wordpress.com/2012/09/15/front-door-of-tourismbuilding-destinations-not-just-piers/ (Retrieved 16 January 2014).

Darley, H 2012b, “Port authorities - not just landlords,” Hugh Darley’s Blog, 3 August, http://hughdarley.wordpress.com/2012/08/03/port-authorities-not-just-landlords/ (Retrieved 16 January 2014).

Darwin Port Corporation (DPC) 2011, Response to the 'towards 2020 tourism in the territory, DPC, Darwin, http://www.tourismnt.com.au/Portals/3/docs/strategy/Darwin_Port_Corporation.pdf.

Di Vaio, A \& Romana Medda, F 2010, Governance and efficiency of Mediterranean cruise terminals. World Conference on Transport Research, Lisbon, http://www.sietitalia.org/siet2010/29-di\%20vaio_medda_paper.pdf.

Dredge, Dianne 2010, "Place change and tourism development conflict: evaluating public interest,” Tourism Management, vol 31, no 1, pp 104-112.

Drobnic, A 2001, “Ship schedules three cruises from Mobile,” Press release - City of Mobile, 14 November, City of Mobile, Alabama, Mobile, http://www.cityofmobile.org/news.php?view=full\&news=110 (Retrieved 10 February 2014).

Eijgelaar, E, Thaper C \& Peeters, P 2010, “Antarctic cruise tourism: the paradoxes of ambassadorship, ‘last chance tourism’ and greenhouse gas emissions,” Journal of sustainable tourism, vol 18, no 3, pp 337-354. 
Elliott, B 2011, "Falmouth not reaping full economic benefits from cruise ship pier," FalmouthPO.com, 15 July, http://falmouthpo.com/blog/business/falmouth-reaping-fulleconomic-benefits-cruise-ship-pier/ (Retrieved 18 February 2014).

Florida-Caribbean Cruise Association (F-CCA) 2013, Cruise industry overview - 2013, F-CCA, Pembroke Pines, http://www.f-cca.com/downloads/2013-cruise-industry-overview.pdf (Retrieved 10 February 2014).

FoxNews.com 2012, “Cruise failure leaves Mobile with looming debt,” FoxNews.com, 7 May, Fox News Network LLC, New York, http://www.foxnews.com/travel/2012/05/07/cruise-failureleaves-mobile-with-looming-debt/ (Retrieved 17 February 2014).

Friedman, A \& Miles, S 2002, “Developing stakeholder theory,” Journal of management studies, vol 39, no 1, pp 1-22.

Galveston Cruise Tips 2014, "Will the Houston (Bayport) cruise terminal overtake the port of Galveston?,” Galveston Cruise Tips, http://www.galvestoncruisetips.com/will-the-houstonbayport-cruise-terminal-overtake-the-port-of-galveston/ (Retrieved 23 February 2014). Gisborneherald.co.nz 2013, “Cruise ships on horizon,” Gisborneherald.co.nz, 10 October, The Gisborne Herald, Gisborne, http://www.gisborneherald.co.nz/article/?id=34392 (Retrieved 15 October 2014).

Government of the Cayman Islands 2011, Location and geography, Government of the Cayman Islands, George Town, http://www.gov.ky/portal/page?_pageid=1142,1481077\&_dad=portal\&_schema=PORTAL (Retrieved 12 February 2014).

Government of the Cayman Islands 2013, Cruise berthing terminal for Cayman Islands - final draft EIA terms of reference, Government of the Cayman Islands, http://www.doe.ky/wpcontent/uploads/2013/11/13.11.13-Cruise-Berthing-Facility-Final-Draft-EIA-Terms-ofReference.pdf (Retrieved 18 February 2014). 
Gui, L \& Russo, A 2011, “Cruise ports: a strategic nexus between regions and global lines evidence from the Mediterranean,” Maritime policy \& management, vol 38, no 2, pp 129-150.

Hill, C \& Jones, T 1992, “Stakeholder-agency theory,” Journal of management studies, vol 29, pp 131-154.

Hritz, N \& Cecil, A 2008, "Investigating the sustainability of cruise tourism: a case study of Key West,” Journal of sustainable tourism, vol 16, no 2, 168-181.

Jamal T \& Getz, D 1995, “Collaboration theory and community tourism planning," Annals of tourism research, vol 22, no 1, pp 186-204.

Jamaica Information Service 2008, US\$224m historic Falmouth development cruise ship pier contract signed, 10 November, Government of Jamaica, Kingston, http://jis.gov.jm/us224mhistoric-falmouth-development-cruise-ship-pier-contract-signed/ (Retrieved 18 February 2014).

Johnson P \& Lyons, K 2011, “Knowledge transfer in a turbulent context: the case of cruise tourism development in Newcastle, Australia," in Gross, M ed 2011, CAUTHE 2011: National Conference: Tourism: creating a brilliant blend, Adelaide, Australia, http://search.informit.com.au.libraryproxy.griffith.edu.au/documentSummary;dn=903066566148 280;res=IELBUS (Accessed 14 October 2014).

Kerswill, M 2013, Big ships, small towns: the impact of new port developments in the cruise tourism industry - the case of Falmouth Jamaica, Masters Thesis, University of Waterloo, Waterloo.

Klein, R 2005, “Turning water into money: the economics of the cruise industry,” pp 261-269, in Dowling, R ed 2006, Cruise ship tourism, CABI, London.

Lekakou, M, Pallis A \& Vaggelas, G 2009, “Which homeport in Europe: the cruise industry's selection criteria," Tourismos, vol 4, no 4, pp 215-240. 
Lester, J \& Weeden, C 2004 . "Stakeholders, the natural environment and the future of Caribbean cruise tourism," International journal of tourism research, vol 6, no 1, pp 39-50.

London, W 2010, Ship to shore: the nexus and optimisation of risk, Ministry of Tourism, Wellington.

Lukes, S 1974, Power: a radical view, Macmillan, London.

McCalla, R 1998, "An investigation into site and situation: cruise ship ports."Tijdschrift voor economische en sociale geografie, vol 89, no 1, pp 44-55.

McCarthy, J \& Romein, A 2012, “Cruise passenger terminals, spatial planning and regeneration: the cases of Amsterdam and Rotterdam,” European planning studies, vol 20, no 12, pp 20332052.

Major, B 2013a, “Cayman ship pier study calls for support from major cruise lines,” Travel pulse, 11 November, http://www.travelpulse.com/news/features/cayman-ship-pier-study-callsfor-support-from-major-cruise-lines.html (Accessed 18 February 2014).

Major, B 2013b, “Major cruise line said to offer to develop Grand Cayman cruise port,” Travel Pulse, 4 February, http://www.travelpulse.com/news/features/major-cruise-line-said-to-offer-todevelop-grand-cayman-cruise-port.html (Retrieved 18 February 2014).

Mak, J 2008, "Taxing cruise tourism: Alaska's head tax on cruise ship passengers," Tourism economics, vol 14, no 3, pp 599-614.

Marti, B 1990, “Geography and the cruise ship port selection process,” Maritime policy and management, vol 17, no 3, 157-164.

Markwick, M 2000, “Golf tourism development, stakeholders, differing discourses and alternative agendas: the case of Malta,” Tourism management, vol 21, pp 515-524. 
Moreno, J 2011, “Idle cruise terminal’s price tag is \$37m higher,” Houston chronicle, 10 June, http://www.chron.com/business/article/Idle-cruise-terminal-s-price-tag-is-37M-higher1547585.php (Retrieved 17 February 2014).

Murtagh, D 2011, “Carnival cruises out of Mobile crushing locals’ terminal dreams,” AL.com, 11 March, Alabama Media Group, http://blog.al.com/live/2011/03/carnival_cruise_lines_cutting.html (Retrieved 29 January 2014).

Peisley, T 2013, “Money talks as ports battle for ships,” pp 10-15, Cruise insights, Spring 2013. http://www.ashcroftandassociates.com/downloads/CI-Spring-2013-Lead-Article.pdf (Retrieved 14 December 2013).

Port of Barcelona 2013a, Barcelona cruise facilities 2013: Europe's leading cruise port, Port Authority of Barcelona, Barcelona, http://www.portdebarcelona.cat/cntmng/d/d/workspace/SpacesStore/cf0389db-4c8d-4064-bf54ef32e5081416/BCF_2013.pdf (Retrieved 22 January 2014).

Port of Barcelona 2013b, “The Port of Barcelona has reached an agreement with Carnival Corporation \& plc who plans to invest over 20 million EUR in a new Cruise Terminal," Press release, 27 September, Port of Barcelona, Barcelona, http://www.portdebarcelona.cat/cntmng/d/d/workspace/SpacesStore/96f22773-68a7-4e1d-aada462c1e189481/130927_NOTAENTerminal_E.pdf (Retrieved 18 February 2014).

PR Web 2011, "Port Authority of Jamaica and Royal Caribbean inaugurate historic Falmouth port,” PR Web, 22 March, Vocus, Herndon, http://www.prweb.com/releases/falmouthjamaica/cruise-vacation/prweb8227023.htm (Retrieved 13 February 2014).

Queensland Government 2005, “Gold Coast cruise ship terminal project board appointed: Bligh,” Media Statement, 12 December, http://statements.qld.gov.au/Statement/Id/43989 (Retrieved 18 February 2014). 
Reuters 2013, "Italy to divert cruise ships from historic Venice,” The telegraph, 5 November, Telegraph Media Group Ltd, London, http://www.telegraph.co.uk/news/worldnews/europe/italy/10429181/Italy-to-divert-cruise-shipsfrom-historic-Venice.html (Retrieved 17 February 2014).

Robbins, S 2011, “Caymans want new dock to keep cruise sector afloat,” Reuters.com, 10 October, http://www.reuters.com/article/2011/10/10/us-cayman-cruiseidUSTRE7994Z620111010 (Retrieved 18 February 2014).

Roehl, W \& Fesenmaier, D 1992, "Risk perceptions and pleasure travel: an exploratory analysis," Journal of travel research, vol 30, no 4, 17-26.

Royal Caribbean Cruise Lines (RCCL) 2011, "Some complain effects of cruises to Falmouth not felt yet,” Royal Caribbean Blog, 4 April, RCCL, Miami, http://www.royalcaribbeanblog.com/2011/04/04/some-complain-effects-cruises-falmouth-notfelt-yet (Retrieved 22 January 2014).

Ryan, M 2012, "Port of Houston offered marketing incentive to attract cruise ships,” Houston business journal,, 16 November, Houston Business Journal, Houston, http://www.bizjournals.com/houston/news/2012/11/16/port-of-houston-offeredmarketing.html?page=all (Retrieved 9 February 2014).

Sautter, E \& Leisen, B 1999, “Managing stakeholders: a tourism planning model,” Annals of tourism research, vol 26, no 2, pp 312-328.

Schmallegger, D \& Carson D 2010, "Whose tourism city is it? The role of government in tourism in Darwin, Northern Territory,” Tourism hospitality planning and development, vol 7, no 2, pp 111-129.

Severson, K 2013, “This Charleston Harbor battle is over cruise ships,” New York Times, 19 February, The New York Times Company, New York, 
http://www.nytimes.com/2013/02/20/us/battle-in-genteel-charleston-over-cruise-ships.html?_r=0 (Retrieved 17 February 2014).

Sharp, J 2013, "Cruise ship talks resurface in Mobile, but industry expert says hopes are fleeting,” AL.com, 30 October, Alabama Media Group, http://blog.al.com/live/2013/10/public_cruise_ship_talks_resur.html (Retrieved 10 February 2014).

Singapore Tourism Board 2009, "Singapore embarks on the construction of the international cruise terminal," Media release, Singapore Government, 2 October, https://app.stb.gov.sg/asp/new/new03a.asp?id=10883 (Retrieved 27 February 2014).

Skene, K 2010, "Broadwater resort and cruise ship terminal one step closer as ASF Consortium gets preliminary approval for casino licence," Gold Coast bulletin, 27 May, http://www.goldcoastbulletin.com.au/news/gold-coast/broadwater-resort-and-cruise-shipterminal-one-step-closer-as-asf-consortium-gets-preliminary-approval-for-casino-licence/storyfnj94idh-1226932299642 (Accessed 14 October 2014).

Stephens, K 2014, “Gold Coast cruise ship terminal plan gets government’s approval,” BrisbaneTimes.com.au, 13 February, http://www.brisbanetimes.com.au/queensland/gold-coastcruise-ship-terminal-plan-gets-governments-approval-20140213-32k2n.html (Accessed 18 February 2014).

Stewart, E \& Draper, D 2006, “Sustainable cruise tourism in Arctic Canada: an integrated coastal management approach,” Tourism in marine environments, vol 3, no 2, pp 77-88.

Stolz, G 2013, "Billionaire developer Bob Ell refloats plans for \$2 billion cruise ship terminal on southern Gold Coast,” The courier mail, 27 December, http://www.couriermail.com.au/news/queensland/billionaire-developer-bob-ell-refloats-plansfor-2-billion-cruise-ship-terminal-on-southern-gold-coast/story-fnihsrf2-1226790709466 (Retrieved 6 February 2014). 
Tejada, P, Santos, F \& Guzmán, J 2011, “Applicability of global value chains analysis to tourism: issues of governance and upgrading,” The service industries journal, vol 31, no 10, pp 1627-1643.

The Gleaner 2008, “It’s a loan, says Port Authority - Royal Caribbean to be repaid US\$102m investment in Falmouth pier,” The Gleaner, 21 November, http://jamaicagleaner.com/gleaner/20081121/business/business3.html (Retrieved 18 February 2014).

The Gleaner 2011, “No Falmouth cruise ship benefit,” The Gleaner, 15 July, http://jamaicagleaner.com/latest/article.php?id=30146 (Retrieved 18 February 2014).

The Gleaner 2012, “Caribbean cruises leave wave of bitter merchants,” Jamaica gleaner, 14 October, http://jamaica-gleaner.com/gleaner/20121014/business/business8.html (Retrieved 8 March 2014).

Tourism NT 2012, “Cruise ships: industry sector profile,” In focus, http:/www.tourismnt.com.au/Portals/3/docs/research/Cruise\%20Fact\%20Sheet\%202011-12.pdf (Retrieved 18 February 2014).

Tourism Queensland 2006, Cruise shipping plan - section B: strategic overview, Tourism Queensland, Brisbane, http://www.tq.com.au/fms/tq_corporate/special_interests/cruise_shipping/Section\%20B\%20\%20Strategic\%20Overview.pdf (Retrieved 18 February 2014).

Wearing, S \& McDonald, M 2002, “The development of community-based tourism: re-thinking the relationship between tour operators and development agents as intermediaries in rural and isolated area communities,” Journal of sustainable tourism, vol 10, no 3, pp 191-206.

Whitaker, J 2013, “Critics urge caution on cruise port deal,” cayCompass.com, 3 December, Cayman Free Press Ltd, Grand Cayman, http://www.compasscayman.com/caycompass/2013/12/03/Critics-urge-caution-on-cruise-portdeal/ (Retrieved 29 January 2014). 
Whitaker, J 2014, "Cruise lines invited to begin talks over berthing dock plan,” cayCompass.com, 4 February, http://www.compasscayman.com/caycompass/2014/02/04/Cruiselines-invited-to-begin-talks-over-berthing-dock-plan/(Retrieved 18 February 2014).

Wie, B 2005, “A dynamic game model of strategic capacity investment in the cruise line industry," Tourism management, vol 26, no 2, pp 203-217.

Willoughby, S \& Ardern, L 2014, “ASF China Property Consortium announced as preferred developer for Broadwater marine project,” The Australian, 13 February, http://www.theaustralian.com.au/news/asf-china-property-consortium-announced-as-preferreddeveloper-for-broadwater-marine-project/story-e6frg6n6-1226825825933 (Retrieved 18 February 2014).

Wood, R 2004, “Cruise ships: deterritorialized destinations,” in Lumsdon, L \& Page, S eds 2004, Tourism and transport: issues and agenda for the new millennium, pp 133-145, Elsevier, Amsterdam.

Yilmaz, B \& Gunel, O 2009, “The importance of strategic stakeholder management in tourism sector: research on probable applications,” Tourismos: an international multinational journal of tourism, vol 4, no 1, pp 97-108. 